\title{
Issues and Challenges of Non-Bank Financial Institutions in Bangladesh
}

\author{
Md. Rizwan Hassan
}

Assistant Professor, International Islamic University Chittagong, Bangladesh

\begin{abstract}
Abstract: The article examines the issues and challenges faced by non-bank financial institutions in Bangladesh. At present the main concern of NBFIs of Bangladesh is collecting fund for investment at a lower cost. Due to current liquidity crisis of banks, it became difficult for them to have funds at a reasonable cost. Other issues stem from severe competition from banks, volatile stock market, and lack of trained human resource and absence of secondary market for loan products. It is suggested that NBFIs have to search for alternative and low cost source of funds, find appropriate way to diversify their product in a manner attractive to people and restrict their investment in low-risk project.
\end{abstract}

Keywords: Non-Bank Financial Institutions, asset-liability mismatch, high risk portfolio.

\section{INTRODUCTION}

$\mathrm{F}^{\mathrm{i}}$ inancial system is most important part of any economy. This financial system comprises banks and non bank financial institutions (NBFIs). Both banks and financial institutions are engaged in mobilizing fund from surplus unit to deficit unit of the economy. Financial institutions are engaged in financial intermediation, exchanging financial assets on own behalf and on customers behalf, assisting in creation of financial assets providing investment advice and managing portfolio of participants (Fabozzi et. at. 2002)

As Bangladesh is an import based economy banks are dominant financial institution in Bangladesh. There are forty seven scheduled banks in Bangladesh licensed under Bank Companies act 1991 (Amended in 2003) under direct supervision and control of Bangladesh bank. In addition to that there are four non-scheduled bank established for special purpose. NBFIs invest in those sectors of economy that is untouched by banks. So, some of the projects chosen by NBFIs are treated as high risk projects. That's why banks blame NBFIs to be high risk takers.

It also helps to increase productions \& encouraging the development of capital markets and money markets. Efforts undertaken by the NBFIs include collecting funds from the public by issuing securities, giving credit especially medium term credit, hold equity in companies or projects.

\section{ObJectives OF THE STUDY}

The study was conducted to fulfill the following objectives

- To discuss the current scenario of NBFIs in Bangladesh.

- To identify some issues and challenges faced by NBFIs in Bangladesh.

- To recommend some measures to overcome those challenges.

Copyright $\odot$ 2013, Asian Business Consortium | ABR

\section{Methodology OF THE STUdY}

The study was conducted using both primary and secondary data. Primary data were collected from interviewing different officers and managers of different non-bank financial institutions. The entire workforce serving in NBFIs was population for the study. For the purpose of interview ten financial institutions were selected randomly most of them were from different types financial institutions. Two officers from each of these institutions were selected based on convenience for interview. So there were twenty interviewees for the study. The interviewees were selected on the basis of their available time to spare for the interview. Secondary data were collected from different books, journals and web sites of Bangladesh Bank and different non-bank financial institutions. The collected data were tabulated and summarized for intended purpose. Different statistical tools were used for this purpose.

\section{The Concept OF NBFI}

As per Bangladesh Bank Non-bank Financial Institutions are financial intermediaries that accumulate funds by borrowing from the general public and lend the same to meet specialized financing needs, but are prohibited to accept such deposits payable either on demand or by cheque, draft, etc. and operate checking accounts for which their liabilities are not a part of the money supply. The definition provided by Bangladesh Bank encompasses only leasing and finance companies. But there are a number of other financial institutions that are also called NBFI. The matter of fact is that all insurance companies, merchant banks and securities houses are NBFIs. The first non-bank financial institution (NBFI) was a fire insurance company established in 1680 in London. Industrial Promotion and Development Company (IPDC) was the first private sector NBFI in Bangladesh, which started its operation in 1981. 
NBFIs are financial institutions that are not allowed to perform the core of banking business. However, some of their activities overlap the activities of banks. NBFIs are institutions that conduct activities in the financial sector; they may work as financial intermediary or other financial services.

In the Bangladesh context, NBFIs are those institutions that are licensed and controlled by the Financial Institutions Act of 1993 (FIA '93). The services range from accepting deposits and extending loans and advances to investment banking functions; from merchant banking to insurance, etc.

\section{Products and Services Offered by NBFIs}

Non-Bank Financial Institutions play a pivotal role in fulfilling the gap of financial services that are not generally provided by the banking sector. The competition among NBFIs is increasing over the years, which is forcing them to diversify to a wider range of products and services and to provide innovative investment solutions. The product and services provided by NBFIs can be categorized as under:

\subsection{Accepting Deposit}

As it has been said deposit products of NBFIs are usually of two types.

- Term Loan: As NBFIs are not allowed to maintain checking account the main deposit product is of term loan. Maturities of these loans vary from one to five years. However maturity other than this is also available for many NBFIs.

- Deposit Pension Scheme: under this scheme deposits are accepted on a periodic basis with equal installment. The future value is payable at the end of the period in a lump sum.

\subsection{Financing}

The following loan products are available.

- Lease financing: One of the most important products of NBFIs is leasing, which facilitate the use of a fixed asset without owning it in exchange of a series of periodic payments. There are different types of leasing that a financial institution can provide. NBFIs usually provide capital lease, operating lease, leveraged lease, sale and lease back, synthetic lease, etc.

- Home loan and real estate financing: House loan and real estate financing is extended for purchase, construction, renovation and extension of apartment \& house, purchase of office space for professionals, purchase and construction of commercial building, real estate development for construction of apartment project. These loans are mostly medium to long term in nature.

- Bridge Finance: Bridge finance fills the gap between the need of fund and availability of fund in the near future. It is extended in anticipation of immediate long term financing such as public issue, private placement, loan syndication, etc.
- Syndication of large loans: Sometimes amount of loan needed is so large that a single institution is not in a position to assume the entire risk. Under such circumstances, a number of financial institutions meet together to finance a huge project.

\subsection{Merchant Banking}

Apart from finance and leasing companies there are some NBFIs that are not involved in extending credit rather they are involved in assisting firms raise funds. They may be involved in the process as any or all of the following.

- Issue Management: The Issue Management group is capable of devising innovative solution to corporate clients for raising capital - debt and equity through private and public placement from the market suiting the unique needs and constraints of the clients.

- Underwriting: Underwriting refers to the guarantee by the underwriters that in the event of under-subscription; the underwriter will take up the under-subscribed amount on pro-rata basis upon payment of price of that option. It is done by a group of underwriters.

- Portfolio Management: Merchant banks offer small investors to open investors' account with merchant banks and provide support for the purchase and sale of shares for the clients. Clients shall have absolute discretionary power to make investment decisions.

- Corporate Advising: Through corporate advising, the merchant bank helps the issuer analyze its financing needs and suggest various ways to raise needed funds and terms and timing of issue.

\subsection{Securities services}

- Brokerage services: members of stock exchanges are allowed to provide brokerage services for Trade Execution, Pre -IPO private placement.

- CDBL services as full service depository participant (DP): Apart from the brokerage services, securities services also provide the services like BO (Beneficial Owner) accounts opening and maintenance, Dematerialization, Re-materialization, Transfers, Lending and borrowing, etc.

\section{FINDINGS AND THEIR ANALYSIS}

From the questionnaire survey and the analysis of financial statements of different NBFIs some interesting facts have been discovered regarding the challenges of faced by them. The main challenge faced by NBFIs is the fact that, they do not collect customer deposits. Customer deposits is the main source of cash for banks and that is why in spite of heavy losses, banks are able to survive whereas NBFIs had to wind up their operations. Mobilizing funds for their operations is the biggest challenge for Non Banking Financial Companies. Other problems are as follows: 


\section{Sources of fund}

NBFIs collect funds from a wide range of sources including financial instruments, loans from banks, insurance companies and international agencies as well as deposits from institutions and the public. Line of credit from banks constitutes the major portion of total funds for NBFIs. Deposit from public is another important source of fund for NBFIs, which has been increasing over the years. According to the central bank regulation, NBFIs has the restriction to collect public deposits for less than six months, which creates uneven competition with banks as banks are also exploring the business opportunities created by NBFIs with their lower cost of fund.

\section{High Cost of fund}

As most of the funds collected by NBFIs are from commercial banks, their cost of fund is much higher than commercial banks. Current scarcity of funds has added to their sufferings. As per Bangladesh Bank, department of statics, the weighted average interest rate for all banks is 8.47 percent on deposit and 13.80 percent on lending in December 2012. On the other hand the deposit interest rate of NBFIs ranges from 14 percent to 16 percent and lending interest rates ranges from 21.5 percent to 18 percent. Thus the weighted average cost of fund for NBFIs would be at least twice that of banks.

\section{Asset Liability Mismatch}

Madura (2009) identified that for all types of depository institutions, it is a normal phenomenon that average maturity of assets are higher than liability, it creates interest rate risk for the financial intermediaries. NBFIs are in a great dilemma while managing the mismatch between their asset and liability. The average weighted life of the company's business portfolio should be less than the average weighted life of its deposits and borrowing. Only one company in Bangladesh was successful in maintaining the above guideline (Banerjee and Mamun (2003)).

\begin{tabular}{|c|c|c|}
\hline $\begin{array}{c}\text { Name of } \\
\text { the NBFIs }\end{array}$ & $\begin{array}{c}\text { Average weighted } \\
\text { life of deposit \& } \\
\text { borrowing (years) }\end{array}$ & $\begin{array}{c}\text { Average weighted } \\
\text { life of the business } \\
\text { portfolio (years) }\end{array}$ \\
\hline IDLC & 2.94 & 2.84 \\
\hline ULC & 3.64 & 4 \\
\hline PLC & 1.92 & 2.5 \\
\hline BLIL & 1.25 & 1.5 \\
\hline PFIL & 3 & 3 \\
\hline BIFCL & 3 & 3 \\
\hline BFICL & N/A & 3 \\
\hline
\end{tabular}

[Source: Banerjee \& Mamun (2003)]

\section{Investment in High Risk Portfolio}

Most of the officers of NBFIs under the survey agreed that they invest in comparatively high risk projects as compared to banks. Reason behind this they identified that as their cost of fund is high they seek return higher than the normal. So they choose projects that are declined by banks on high risk ground. It may create unhealthy balance sheet for those NBFIs.

Copyright $(C 2013$, Asian Business Consortium | ABR

\section{Poor Capital Market Condition}

The stock market has been performing very poorly since early 2010. More than three million small investors lost their capital. They were forced to protest in the street. This market crash accompanied by sluggish economy affected the NBFIs abruptly. The trade declined drastically reducing the revenue for the securities houses and NBFIs that maintain a portfolio also faced huge loss due to price reduction.

\section{Competition with Banks}

NBFIs serve the portion market that is untouched by the banks that is it left over. In our country, three are forty seven commercial banks and some nine are under process of starting their operation. So there is a severe competition for selling loan products. It becomes tougher when commercial banks engage in non-bank activities.

\section{Lack of Human Resource}

Skilled and trained human resource is considered as an important component for the development of any institution. Due to the recent growth of NBFIs, availability of experienced manpower is a challenge for this industry. The supply shortage of efficient resource personnel has been leading to a significant increase in the compensation package, which is also a cause of concern for NBFIs.

\section{Weak Legal System}

Nasreen and Jahan (2007) pointed that weak legal system creates a problem for leasing companies. Islam (1999) showed that legal system hinders growth of leasing companies in Bangladesh. Although the default culture has not yet infected NBFIs to any major extent, they face difficulties in recovering the leased assets in case of a default. Another legal aspect that the leasing companies face is right of depreciation for leased like many countries.

\section{Lack of a Secondary Market}

Even in cases when the defaulted asset is recovered, the disposal of the same becomes difficult because of lack of an established secondary market. For the promotion of a secondary market, NBFIs may consider initiating the concept of operating lease instead of the prevalent mode of finance lease in case of these recovered assets to create a demand for second hand or used machinery and equipment.

\section{Suggested Alternatives}

\section{Exploring Alternative Sources of Funds}

The NBFIs should take initiative to explore alternative source of fund like issuance of commercial paper and discounting or sale of lease receivables to ease the fund crisis and reduce the cost of fund. Another innovative and promising source of funds may be the securitization of assets. In this connection, IPDC launched first asset backed securities in 2004 as an alternative source of funding. The government and Bangladesh Bank should provide necessary policy support in this regard.

\section{Using Floating Interest Rates}

We know one of the most important issues facing any lend- 
ing organization is asset liability mismatch. If NBFIs can match the duration of it asset products with its loan products it can solve the problem. But it is next to impossible. So, NBFIs can use floating interest rate in its entire lending.

\section{Using interest rate swap}

Interest rate swap is an arrangement by which one set of fixed interest payment is exchanged for variable one and vice versa (Madura 2008). Financial institutions that have more interest rate-sensitive liability than assets are adversely affected by increasing interest rate. Conversely, financial institutions that have long-term fixed rate funding, but uses the funds primarily for floating rate loans are adversely affected by declining interest rate. These financial institutions can successfully use interest rate swap to hedge interest rate risk.

\section{Investment in Optimum Risk Assets}

Optimal capital allocation is a tradeoff between risk aversion and optimum expected return (Bodie 2009). Investment only in high risk assets reduces rating of an organization. So NBFIs should invest in assets that are of standard risk. In this regard they may follow the guidelines of BASEL-II. In country, Delta-Brac housing has consistently maintained the high rating for several years.

\section{Improving Capital Market}

NBFIs around the world carry out a significant role in the development of the capital market. Strong institutional support is necessary for a vibrant capital market which is the core of economic development in any market based economic system. NBFIs through their merchant banking wing can act in this regard. A total of 30 companies are now listed as merchant banks in Bangladesh, of which 23 are full-fledged, 6 are issue managers, and only one is a portfolio manager. Only nine NBFIs have registered with SEC for performing merchant banking activities.

\section{Developing Human Resource}

The NBFIs should try to improve their human resources to compete in the market based economy. They may arrange different seminar, workshop and other training programs to improve the quality of workforce of their respective organizations.

\section{Development of Commensurate Legal framework}

A modern and dynamic regulatory framework is required for the rapid and effective development of NBFIs. The NBFIs are now regulated by the Financial Institutions Act 1993 and Financial Institutions Regulations 1994. Some weaknesses of these regulations have been identified. NBFI regulations should be the classification into deposit and non-deposit takers. Those NBFIs activities are involved with the capital market that is those obtain funds through public offering of securities should be under the regulatory jurisdiction of the Security and Exchange Commission.

\section{CONCLUSION}

Banks and Non-Bank Financial Institutions are both key elements of a sound and stable financial system. Banks usually dominate the financial system in most countries because businesses, households and the public sector all rely on the banking system for a wide range of financial products to meet their financial needs. However, by providing additional and alternative financial services, NBFIs have already gained considerable popularity both in developed and developing countries. In one hand these institutions help to facilitate long-term investment and financing, which is often a challenge to the banking sector and on the other; the growth of NBFIs widens the range of products available for individuals and institutions with resources to invest. Through their operation NBFIs can mobilize long-term funds necessary for the development of equity and corporate debt markets, leasing, factoring and venture capital. Another important role which NBFI's play in an economy is to act as a buffer, especially in the moments of economic distress. An efficient NBFI sector also acts to mitigate systemic risk and contributes to the overall goal of financial stability in the economy.

NBFIs of Bangladesh have already passed more than two and a half decades of operation. Despite several constraints, the industry has performed notably well and their role in the economy should be duly recognized. It is important to view NBFIs as a catalyst for economic growth and to provide necessary support for their development. A long term approach by all concerned for the development of NBFIs is necessary. Given appropriate support, NBFIs will be able to play a more significant role in the economic development of the country.

\section{REFERENCES}

Ahmed, Md. Nehal, Chowdhury, Mainul Islam, (2007) "Non-Bank Financial Institutions in Bangladesh: An Analytical review" working paper series, Bangladesh Bank

Banerjee, P. K. and Mamun, A.A (2003), “Lease Financing in Bangladesh", BIBM Research Paper

Bangladesh Bank (2006), "Financial Sector Review", Vol.1, No.1 May, Policy Analysis Unit, Research Department.

Bangladesh Bank, Annual Report (Various Issues)

Bangladesh Bank, Economic Trends (Various Issues)

Bodie, Zvi, et. al. (2009) "Investments" eighth edition, McGraw Hill International, pp. 194

Fabozzi, Frank J., et. al. (2002) "Foundations of Financial Markets and Institutions" $3^{\text {rd }}$ edition, Pearson Education Asia, pp.15

M. A. Islam, Growth and development of leasing business in Bangladesh: An evaluation Khulna University Studies 1(2): 311-317.

Madura, Jeff (2008), "Financial Markets and Institutions" eighth edition, Thompson South-western corporation, pp.213-214 \&402403

Nasreen, Taslima, Jahan, Mosammet Asma, 'Lease Accounting Practice of Leasing Companies in Bangladesh: A Lessor's Disclosure Perspective" The Cost and Management, Vol. 35 No. 6

Official website of Insurance Development \& Regulatory Authority Bangladesh http://www.idra.org.bd

$--0$ 